\title{
Risks from Past, Current, and Potential Hanford Single Shell Tank Leaks
}

\section{A Systems-Based Understanding of Risks Associated With Tank Leaks}
MB Triplett
DJ Watson
DM Wellman

May 2013

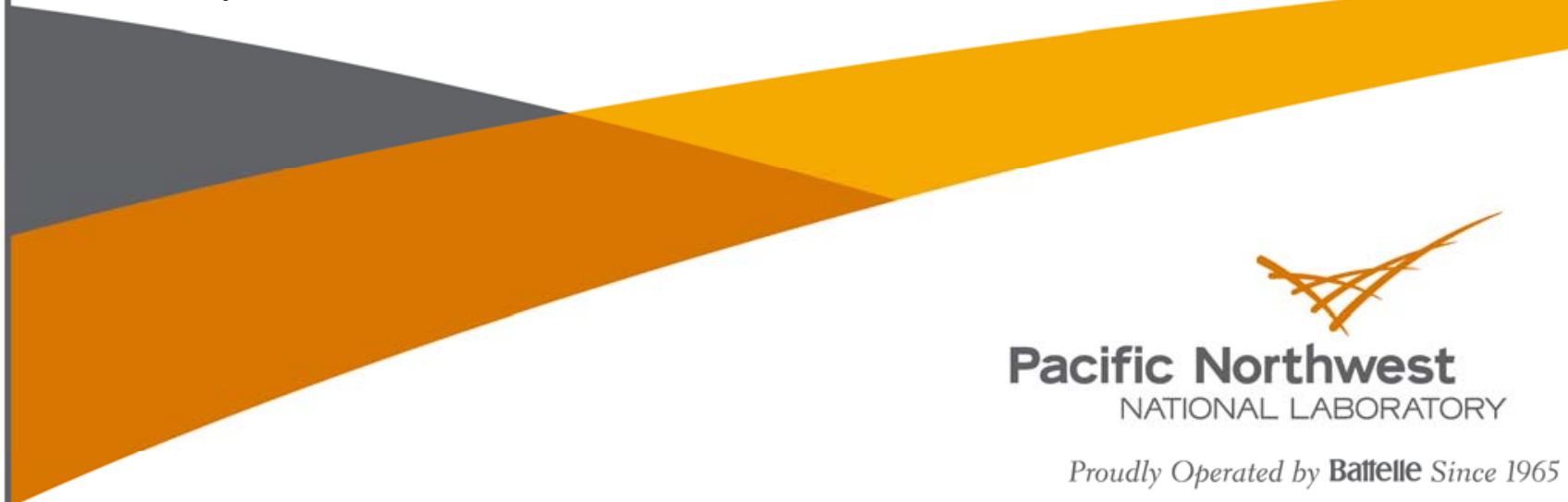




\title{
DISCLAIMER
}

This report was prepared as an account of work sponsored by an agency of the United States Government. Neither the United States Government nor any agency thereof, nor Battelle Memorial Institute, nor any of their employees, makes any warranty, express or implied, or assumes any legal liability or responsibility for the accuracy, completeness, or usefulness of any information, apparatus, product, or process disclosed, or represents that its use would not infringe privately owned rights. Reference herein to any specific commercial product, process, or service by trade name, trademark, manufacturer, or otherwise does not necessarily constitute or imply its endorsement, recommendation, or favoring by the United States Government or any agency thereof, or Battelle Memorial Institute. The views and opinions of authors expressed herein do not necessarily state or reflect those of the United States Government or any agency thereof.

\author{
PACIFIC NORTHWEST NATIONAL LABORATORY \\ operated by \\ BATTELLE \\ for the \\ UNITED STATES DEPARTMENT OF ENERGY \\ under Contract DE-AC05-76RL01830
}

Printed in the United States of America
Available to DOE and DOE contractors from the Office of Scientific and Technical Information,
P.O. Box 62, Oak Ridge, TN 37831-0062;
ph: (865) 576-8401
fax: $(865)$ 576-5728
email: reports@adonis.osti.gov

\begin{abstract}
Available to the public from the National Technical Information Service, U.S. Department of Commerce, 5285 Port Royal Rd., Springfield, VA 22161 ph: (800) 553-6847 fax: $(703) 605-6900$ email: orders@ntis.fedworld.gov online ordering: http://www.ntis.gov/ordering.htm
\end{abstract}

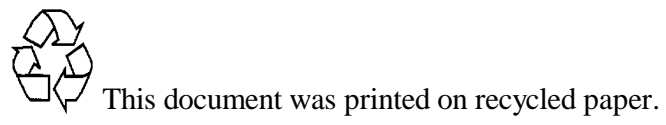




\title{
Risks from Past, Current, and Potential Hanford Single Shell Tank Leaks
}

\author{
A SYSTEMS-BASED UNDERSTANDING OF RISKS ASSOCIATED WITH TANK LEAKS
}

\section{Summary}

Due to significant delays in constructing and operating the Waste Treatment Plant, which is needed to support retrieval of waste from Hanford's single shell tanks (SSTs), SSTs may now be required to store tank waste for two to three more decades into the future. Many SSTs were built almost 70 years ago and all SSTs have greatly exceeded their design lives. Recent examination of monitoring data suggests several of the tanks that were interim stabilized a decade or more ago may be experiencing small leaks (perhaps 150-300 gallons per year) to the subsurface environment. A potential leak from tank T-111 is estimated to have released approximately 2,000 gallons into the subsurface. Observations of past leak events, recently published simulation results, and new simulations all suggest that recent leak events are not likely to impact underlying groundwater above regulatory limits. However, these recent observations remind us that much larger source terms are still contained in the tanks and are also present in the vadose zone from historical intentional and unintentional releases. Recently, significant improvements have been made in methods for detecting and characterizing soil moisture and contaminant releases, understanding and controlling mass-flux, and remediating deep vadose zone and groundwater plumes. To ensure extended safe storage of tank waste in SSTs, the following actions are recommended:

1. Improve capabilities for intrusion and leak detection.

2. Develop defensible conceptual models of intrusion and leak mechanisms.

3. Apply enhanced subsurface characterization methods to improve detection and quantification of moisture changes beneath tanks.

4. Maintain a flux-based assessment of past, present, and potential tank leaks to assess risks and to maintain priorities for applying mitigation actions.

5. Implement and maintain effective mitigation and remediation actions to protect groundwater resources.

These actions will enable limited resources to be applied to the most beneficial actions. A systems-based approach will support extended safe storage of tank waste, reduce the risks from tank leaks, and protect human health and the environment.

\section{Introduction}

The U.S. Department of Energy's (DOE's) legacy waste inventory includes approximately 90 million gallons of radioactive waste stored in 230 single and double shell underground storage tanks at sites across the DOE complex-Hanford (177 tanks), Idaho (4 tanks), and Savannah River (49 tanks). The Hanford Site's 177 tanks consist of 149 single shell tanks (SSTs) and 28 double shell tanks (DSTs) containing approximately 55 million gallons of waste. Sixty-seven of Hanford's SSTs have, or are suspected to have, released up to 1 million gallons 
of waste to the soil, with additional releases from underground transfer lines. DST wastes are not considered here because they are not believed to be leaking to the subsurface.

Between the early 1980s and 2004, DOE transferred pumpable liquid from SSTs into double-shell tanks (DSTs) - a process known as interim stabilization. ${ }^{1}$ However, because of the nature of the waste contained in the SSTs, it was not possible to remove all liquid from each tank. After interim stabilization, liquid can reside in void spaces within the waste-analogous to water in a sponge-making it difficult to remove completely. A breach in the tank could allow the residual liquid to leak. Today, approximately 2.8 million gallons of $\boldsymbol{d r a i n a b l e}$ liquid remains in Hanford's 149 SSTs (Rodgers 2012).

A recent routine examination of surface and interstitial liquid level data from Hanford's SSTs suggests that surface and interstitial liquid levels are declining in several of the tanks, which were interim stabilized a decade or more ago. Surface and interstitial liquid monitoring data for tank T-111 suggests it could be leaking. In addition, on February 22, 2013, 5 of the 20 tanks that DOE is currently evaluating in more detail were publicly declared to be leaking: TY-105, B-203, B-204, T-203, T-2042 (Cary 2013). Because the impact of these five tank leaks is still being evaluated, they are not discussed here. However, an analysis of the leak from tank T-111 can be used as a surrogate for understanding the potential impact tank leaks of similar volumes.

An analysis of the T-111 tank leak is presented in the sections that follow by 1) summarizing the available information on the T-111 leak to describe its magnitude; 2) comparing the potential impacts of the T-111 leak to past tank leaks by examining groundwater impacts and reviewing published simulation results for analogous releases from tank farms; and 3) reporting on new simulation results that provide insight into factors that may mitigate tank leak impacts. In the final section, a systems-based approach is described for improving our understanding of tank leaks and for developing a strategy for managing the risks of extended waste storage in SSTs.

\footnotetext{
${ }^{1}$ Interim stabilization is defined as "the removal of pumpable supernatant and interstitial liquid from SST systems into DST systems. As much liquid as practicable will be removed. Supernatant is free standing liquid. Interstitial liquid is that liquid in the waste matrix contained within the pore spaces of the salts and sludges, some of which is capable of gravity drainage while the rest is held by capillary forces" (from Tri-Party Agreement change request M-41-99-01). The interim stabilization program aimed to reduce supernatant liquid to less than 5,000 gallons and drainable interstitial liquid to less than 50,000 gallons for each SST.

2 The four 200 series tanks show nearly identical declining surface level trends for a period of about 10 years. The rate of decline has been very constant at roughly 0.7 inches per year. If visual inspection of these tanks shows a liquid surface, evaporation calculations will be prepared to determine if surface reductions can be explained by evaporation. All four tanks show surface levels that vary with seasonal temperature changes, suggesting that there is a liquid surface and retained gas in the tank waste. Consequently, evaporation could explain the steady and consistent reduction in surface levels.
}

Page 2

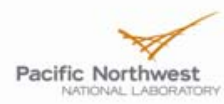


PNNL-22483

\section{Situation Analysis}

\section{T-111 Tank Leak}

In 1994, T-111 was designated as an assumed leaking tank. ${ }^{3}$ Based on analysis of trends in surface and liquid level monitoring data, it appears that this tank leak could be between 150 and 300 gallons per year since 2006 or 2007. The most recent rate of liquid level decline suggests the leak rate could be even higher today, perhaps 1,000 gallons per year. For this evaluation, it is assumed that a possible total leak of roughly 2,000 gallons has occurred. There is significant uncertainty associated with estimating the suspected tank leak rate due to a number of confounding factors, which include the following:

- The type and calibration of the instrument used for measuring the surface. Generally, visual inspection is required to determine if a particular instrument is measuring a responsive liquid surface or if it is measuring a stable or unstable solid surface.

- Water intrusion that could be adding to the level of the liquid in the tank.

- Evaporation that could cause a liquid level decrease.

- Gas generation, buildup/retention and release mechanisms that affect the tank surface levels.

Because of the depth of the tanks, leaks do not threaten workers or future users at the ground surface. However, leaks could migrate through the soil (vadose zone) to the underlying groundwater. Several constituents in tank leaks account for most of the potential long-term risk. The dominant risk contributors from tank leaks are long-lived radionuclides that tend to move with water. Technetium- $\left.99{ }^{99} \mathrm{Tc}\right)$ and uranium are the highest risk radionuclides that can threaten groundwater. Non-radionuclides, such as chromium and nitrate, are also contaminants that pose a risk. In this analysis, ${ }^{99} \mathrm{Tc}$ is used to analyze the potential risks from past, current, and potential tank leaks.

Currently, T-111 is estimated to contain 38,000 gallons of drainable interstitial liquid (Rodgers 2012), just under 447,000 gallons of sludge, and 16.6 curies of ${ }^{99} \mathrm{Tc}$ (PNNL 2013). For this tank, the Best-Basis Inventory does not estimate the inventory residing in the liquid phase. Therefore, the following assumptions were used to estimate the ${ }^{99} \mathrm{Tc}$ inventory that could have been released:

- An upper bound estimate would assume that all of the ${ }^{99} \mathrm{Tc}$ is contained in the drainable interstitial liquid (or liquid phase).

- A lower bound would assume that the ${ }^{99} \mathrm{Tc}$ is evenly distributed in the solid and liquid phases.

Table 1 shows ${ }^{99} \mathrm{Tc}$ release estimates for a possible leak volume of 2,000 gallons based on these two assumptions.

\footnotetext{
${ }^{3}$ In 1974, T-111 was suspected of leaking. It was taken out of service and most of the free liquid waste was pumped out. Then in 1994, a review of tank surface and liquid level monitoring data showed an inexplicable surface drop. T-111 was then classified as an "assumed re-leaker" (Engelman and Jenkins 1994). Interim stabilization was completed in 1994 and 1995. The current estimate for the volume of the prior leak(s) is 1,000 gallons (Jones et al. 2000).
}

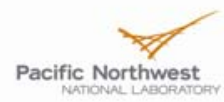


Table 1. Range of Estimated ${ }^{99} \mathrm{Tc}$ Inventory for T-111 Assumed Leak

\begin{tabular}{|c|c|c|}
\hline $\begin{array}{l}\text { Assumption for Distribution of } \\
\mathrm{T}-111{ }^{99} \mathrm{Tc} \text { Inventory }\end{array}$ & ${ }^{99} \mathrm{Tc}$ Concentration in Liquid Phase & ${ }^{99} \mathrm{Tc}$ Released in a 2,000 Gallon Leak ${ }^{\mathrm{a}}$ \\
\hline $\begin{array}{c}\text { All }{ }^{99} \mathrm{Tc} \text { inventory contained in the } \\
\text { drainable interstitial liquid }(38,000 \\
\text { gallons) }\end{array}$ & $437 \mu \mathrm{Ci}$ per gallon & $0.874 \mathrm{Ci}$ \\
\hline $\begin{array}{l}{ }^{99} \mathrm{Tc} \text { inventory uniformly distributed } \\
\text { in solid and liquid phases }(447,000 \\
\text { gallons) }\end{array}$ & $37 \mu \mathrm{Ci}$ per gallon & $0.074 \mathrm{Ci}$ \\
\hline
\end{tabular}

\section{Perspective on Past and Present Tank Leaks}

Figure 1 shows the estimated leak volumes and ${ }^{99} \mathrm{Tc}$ inventories for SSTs, including the estimates for T-111 that were calculated in Table 1. The estimated inventory released from the T-111 tank is much smaller (by 1-2 orders of magnitude) than many prior SST releases, and the estimated volume is also much smaller (also by 1-2 orders of magnitude). Total past leak volume from all SSTs is $\sim 1$ million gallons and $\sim 100 \mathrm{Ci}$ of ${ }^{99} \mathrm{Tc}$ (DOE 2008).

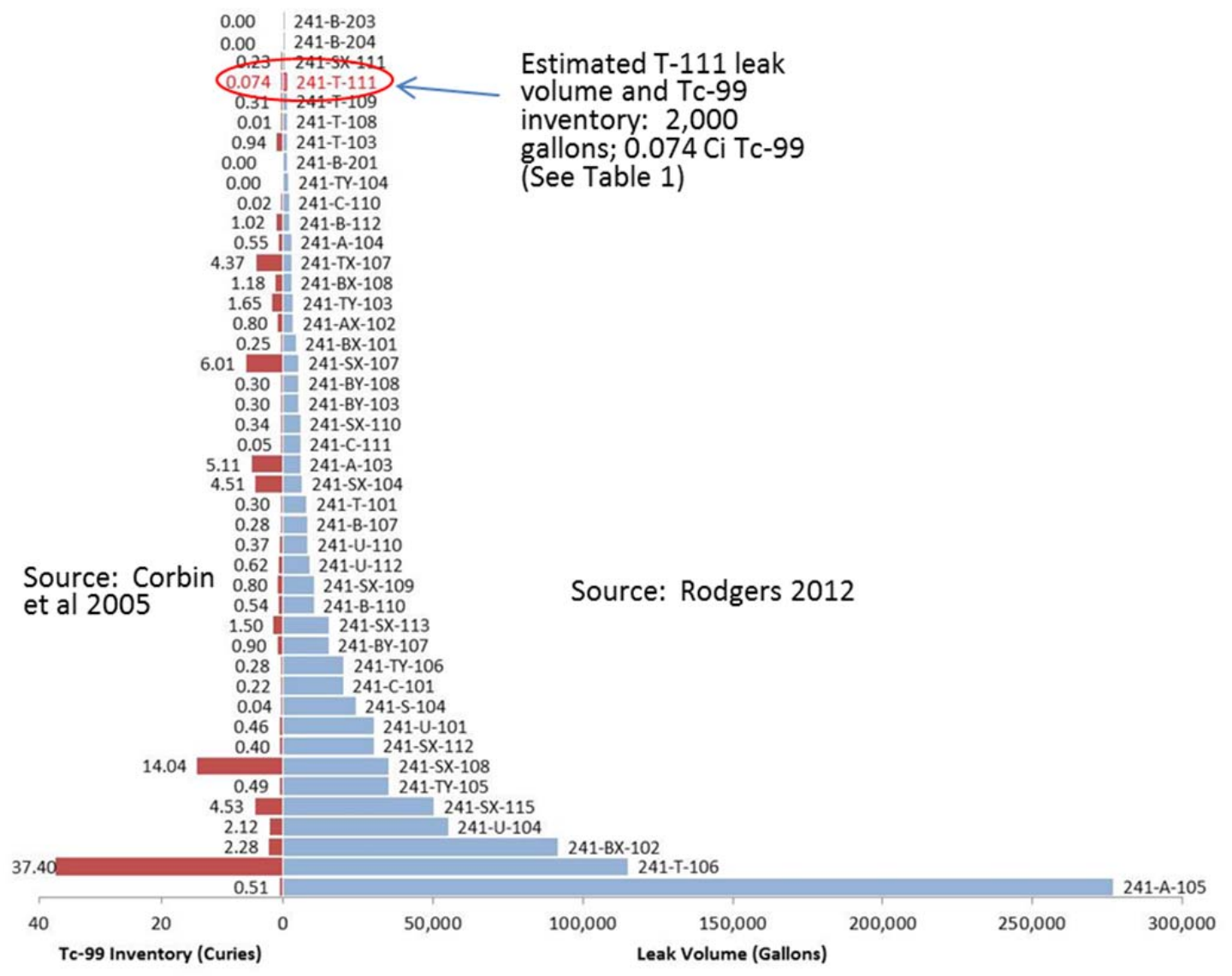

Figure 1. Comparison of Total Drainable Liquid in SSTs and Inventory of ${ }^{99} \mathrm{Tc}$ 
Past leaks from SSTs are known to have reached groundwater in several areas of the Central Plateau at the Hanford Site. The three past tank farm releases that are having the most significant impact on groundwater today are from T-106, BX-102, and multiple releases from SX tank farm. Compared to groundwater plumes from historical discharges of $\sim 450$ billions gallons, plumes from past tank leaks are relatively smaller in areas and higher in concentration. ${ }^{4}$ Those intentional discharges occurred during Hanford's operational period and were discontinued in the early 1990s.

A summary of the most significant past releases from tanks is provided below. This information indicates that past releases have impacted groundwater with contaminant concentrations more than 100 times greater than drinking water standards in several areas. Important mitigating measures have been taken, but further actions are needed to protect the environment.

- Tank T-106. A leak event in 1973 released about 115,000 gallons and $\sim 37 \mathrm{Ci}{ }^{99} \mathrm{Tc}$. In 2005 and 2006, ${ }^{99} \mathrm{Tc}$ in groundwater exceeded the drinking water standard by a factor greater than 200 . An initial interim action to contain the plume was put in place in 2007 with installation of two interim pump-andtreat wells. Then, in 2008, an interim barrier was installed over the center of mass of the past release to reduce water infiltration and lessen the driving force on the contaminants remaining in the vadose zone. More recently, the pump-and-treat wells have been connected to the 200 West Area groundwater treatment system that is being used to treat multiple groundwater plumes, including a $13 \mathrm{~km}^{2}$ plume of carbon tetrachloride.

- Tank BX-102. A tank overfill event in 1951 is believed to have released at least 70,000 gallons of tank waste containing $\sim 10,000 \mathrm{~kg}$ of uranium (Serne et al. 2010). Uranium from the leak reached groundwater sometime between 1998 and 2003, approximately 50 years after the leak event. Uranium concentrations in groundwater have risen sharply in the past 5 years, exceeding the drinking water standard by a factor of 100 . There is also a perched water zone $\sim 20$ feet above the aquifer that contains uranium at more than 2,000 times drinking water standards. An interim action was initiated in 2010 by removal and treatment of the very high concentration perched water. Additional efforts may still be needed to reduce continued flux of uranium to the groundwater or to contain and treat the groundwater itself.

- S-SX Tank Farms. Multiple tanks are known to have leaked with the total volume and inventory of ${ }^{99} \mathrm{Tc}$ comparable to T-106. A small groundwater plume southeast of the SX tank farm has resulted in concentrations of technetium in groundwater that have been as high as 200 times the drinking water standard. Two extraction wells for the 200 West Area pump-and-treat system have been installed to contain and treat emerging ${ }^{99} \mathrm{Tc}$ plumes from S and SX farms. Washington River Protection Solutions is preparing a test of pore water extraction technology during FY 14. This technology is a potential mitigation measure that could reduce contaminant mass in the subsurface and reduce flux to the groundwater.

\footnotetext{
${ }^{4}$ The largest plumes (as measured by the area above the drinking water standard) from non-tank farm discharges are for tritium $\left(103 \mathrm{~km}^{2}\right)$, iodine-129 $\left(60 \mathrm{~km}^{2}\right)$, and nitrate $\left(38 \mathrm{~km}^{2}\right)$. By contrast, the uranium plume associated with the BX-102 uranium release is about $0.3 \mathrm{~km}^{2}$ and the ${ }^{99} \mathrm{Tc}$ plume associated with the T-106 leak is about $0.03 \mathrm{~km}^{2}$ (DOE 2011).
}

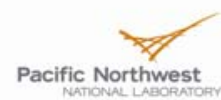


Impacts to groundwater from historical leaks were amplified by flooding events and leaking water lines. These factors have been mostly eliminated in the past decade (DOE 2008), and as a result the downward driving force to groundwater has been significantly reduced. The importance of controlling these driving factors underscores the necessity of a systems-based understanding of subsurface transport.

\section{Prior Estimates of Impacts from Tank Leaks}

One way to estimate the possible impact of the current T-111 leak is to consider similar releases evaluated by recent simulation studies. Releases of similar magnitude to the T-111 leak have been evaluated in both the SST Performance Assessment (DOE 2006) and in the Tank Closure and Waste Management Environmental Impact Statement (EIS) (DOE 2012). Both studies evaluated the impact from hypothetical leaks that could occur during retrieval (Table 2). While not exactly comparable to the current situation, these published results provide insights into possible impacts from the T-111 event. These studies evaluate leaks that could occur during retrieval operations (assumed to be 4,000-8,000 gallons per tank). These estimated leaks are similar, but greater in volume, to the estimated T-111 leak. All of the predicted impacts from hypothetical retrieval leaks are well below the drinking water standard of $900 \mathrm{pCi} / \mathrm{L}$ for ${ }^{99} \mathrm{Tc}$.

Table 2. Results from EIS and the SST PA Analyses for Hypothetical Leaks during Retrieval

\begin{tabular}{|c|c|c|c|c|}
\hline Source & $\begin{array}{c}\text { Source of } \\
\text { Release }\end{array}$ & $\begin{array}{l}{ }^{99} \mathrm{Tc} \\
\text { Inventory of } \\
\text { Release }\end{array}$ & $\begin{array}{c}{ }^{99} \mathrm{Tc} \text { Peak } \\
\text { Concentration }(\mathrm{pCi} / \mathrm{L}) \\
\text { [Year of Peak Impact] } \\
\text { - Drinking Water } \\
\text { Standard }=900 \mathrm{pCi} / \mathrm{L}\end{array}$ & Assumptions \\
\hline \multirow[t]{5}{*}{$\begin{array}{l}\text { EIS (DOE } \\
\text { 2012) }\end{array}$} & $\begin{array}{l}\text { A, AX, C } \\
\text { farms }\end{array}$ & 22.6 & 94 [2063] & \multirow{5}{*}{$\begin{array}{l}\text { A } 4,000 \text {-gallon leak was assumed to occur for all } \\
\text { SSTs during retrieval. For modeling purposes, } \\
\text { all retrieval leaks were assumed to occur in } 2018 \text {. } \\
\text { Peak groundwater concentrations are reported } \\
\text { at the boundary of each barrier. The inventory } \\
\text { contained in the retrieval leaks was assumed to } \\
\text { be proportional to the total amount of }{ }^{99} \mathrm{Tc} \text { in } \\
\text { the tank per unit volume, but diluted by a factor } \\
\text { of four to account for the use of multiple } \\
\text { sluicing campaigns. (See Section D.1.6, DOE } \\
\text { 2012) }\end{array}$} \\
\hline & $\begin{array}{l}\mathrm{B}, \mathrm{BX}- \\
\mathrm{BY} \text { farms }\end{array}$ & 11.0 & 162 [2065] & \\
\hline & $\begin{array}{l}S, S X \\
\text { farms }\end{array}$ & 11.9 & 99 [2082] & \\
\hline & $\begin{array}{l}\text { T, TX, } \\
\text { TY farms }\end{array}$ & 13.2 & 218 [2080] & \\
\hline & $\mathrm{U}$ farm & 7.0 & 49 [2085] & \\
\hline $\begin{array}{l}\text { SST } \\
\text { Performance } \\
\text { Assessment } \\
\text { (DOE 2006) }\end{array}$ & $\begin{array}{l}\text { T-111 } \\
\text { row of } \\
\text { tanks }\end{array}$ & 0.23 & 108 [2066] & $\begin{array}{l}\text { An } 8,000 \text {-gallon leak was assumed from all tanks } \\
\text { starting } 01 / 01 / 2000 \text { and occurring over a } \\
\text { 14-day period. Impacts were calculated for the } \\
\text { row of tanks that could contribute to a } \\
\text { combined groundwater impact. Tanks in this } \\
\text { row were T-110, T- } 111, \mathrm{~T}-112, \mathrm{~T}-203 \text {, and T- } \\
\text { 204. The hypothetical leak from T- } 111 \\
\text { contributed nearly all of the groundwater impact } \\
\text { from this subset of tanks. }\end{array}$ \\
\hline
\end{tabular}

Note: The EIS and SST results are not directly comparable because of differences in the modeling assumptions, e.g., size and timing of assumed retrieval leaks. However, the estimated impacts from potential leaks during retrieval are of similar magnitude and well below regulatory standards. 
PNNL-22483

\section{The Potential for Future Tank Leaks}

Not all SSTs pose the same threat to the environment. Current information about tank conditions and contents points to those tanks that would pose a relatively greater risk to the environment if a new leak were to occur.

Two key factors in determining the potential threat of SSTs are the volume of drainable liquid (the amount of liquid that could be released) and the inventory of constituents important to risk. Today, SSTs show considerable variation in their volume of drainable liquid and inventory of ${ }^{99} \mathrm{Tc}$. Figure 2 plots the drainable liquid and ${ }^{99} \mathrm{Tc}$ inventory for Hanford's SSTs (other than C Farm tanks that are currently being retrieved). As shown in this figure, T-111 has a relatively low ${ }^{99} \mathrm{Tc}$ inventory. One tank clearly stands out from the rest: at 90,000 gallons, A-103 has nearly double the drainable liquid volume as the tank containing the second highest volume, BY-103.

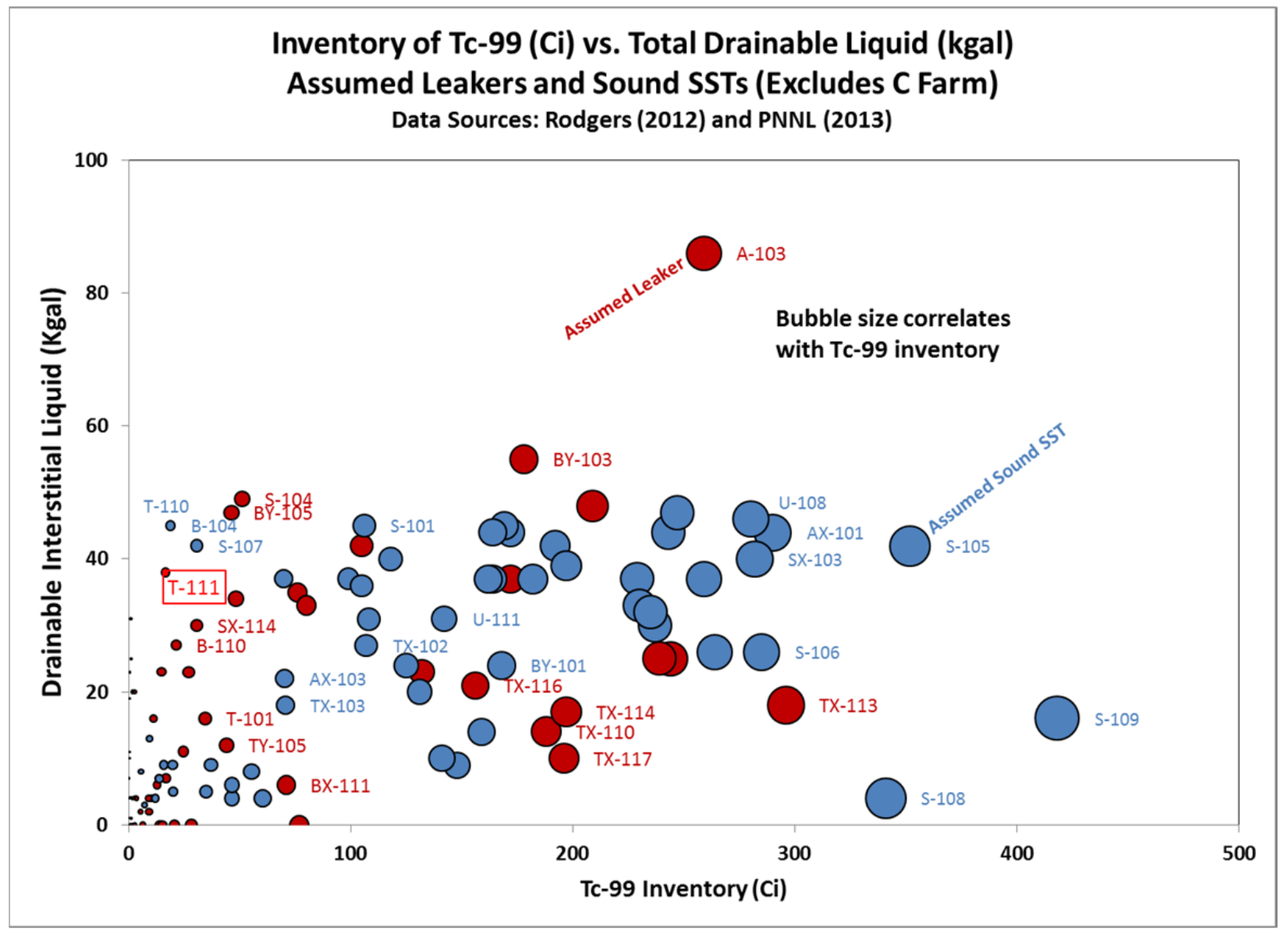

Figure 2. Comparison of Total Drainable Liquid and Total Estimated Inventory of ${ }^{99} \mathrm{Tc}$ for SSTs (other than C Tank Farm) 


\section{Sensitivity Analysis of Potential Tank Leak Impacts}

The impact that tank leaks can have on the groundwater depends on many different factors. This section describes how the tank leak impacts could vary depending on the rate of release from the tank, water flux through the soil, and timing for installing a surface infiltration barrier. Results from these sensitivity cases provide insights into mitigation actions that could be taken.

Understanding subsurface water flux is essential to understanding the potential impact of a tank leak. An important measure of water flux is the recharge rate. Recharge rate is a measure of the volume of water that drains into the underlying groundwater. At the Hanford Site, typical rainfall is about $160 \mathrm{~mm}$ per year ( $\sim 6$ inches per year). A typical recharge rate for Hanford's undisturbed soil and vegetation conditions is about $3.5 \mathrm{~mm}$ per

year. Hanford's arid environment results in relatively low water flux to groundwater. Tank farms, however, have gravel surfaces designed to control and contain contamination to aid in worker safety. The gravel surface at tank farms allows much higher infiltration of water that results in a recharge rate of about $100 \mathrm{~mm}$ per year.

To better understand the effects on peak groundwater concentrations due to variation in key parameters, a series of sensitivity cases were executed with the Subsurface Transport Over Multiple Phases (STOMP) simulator. For these simulations, transport of the release of a unit mass (1 curie) of ${ }^{99} \mathrm{Tc}$ was simulated. This mass was contained in a total leak volume of 2,000 gallons. An existing conceptual model built for the STOMP simulator at S-SX tank farm (Zhang et al. 2004) was used to simulate the T-111 tank leak. This approach provides consistency with the SST Performance Assessment (DOE 2006) and facilitates rapid analysis by taking advantage of an existing conceptual model. The S-SX tank farm conceptual model was used because of similarities in the distance to groundwater and the stratigraphy at the two tank farms.

Three sets of simulations were performed, each varying a different parameter. The first set of simulations varied the leak rate from 150 gallons per year to 4,000 gallons per year (using a fixed leak volume of 2,000 gallons and a fixed recharge of $100 \mathrm{~mm}$ per year), the second varied recharge rate from $3.5 \mathrm{~mm}$ per year to $100 \mathrm{~mm}$ per year (using a fixed leak volume of 2,000 gallons and a fixed leak rate of 450 gallons per year), and the third varied the year in which an infiltration barrier was emplaced from 2 years after the leak occurs to 100 years after (using 2,000-gallon volume, 450 gallon per year leak rate, and $100 \mathrm{~mm}$ per year pre-barrier recharge rate). The first and second series of simulations assumed that no infiltration barrier was placed over the tank farm.

Figures 3, 4, and 5 show the results for variations in leak rate, recharge rate, and time before an infiltration barrier is installed. All results are reported in terms of the peak ${ }^{99} \mathrm{Tc}$ concentration in groundwater reported as $\mathrm{pCi} / \mathrm{L}$ for $1 \mathrm{Ci}$ of ${ }^{99} \mathrm{Tc}$ released during a leak event. Figure 3 shows that a faster leak rate increases the peak concentration, but in general, has a negligible effect on the peak groundwater concentration for the range of leak rates used in this sensitivity analysis. Figure 4 shows that a reduction in the recharge rate from $100 \mathrm{~mm}$ per year to $3.5 \mathrm{~mm}$ per year reduces the peak groundwater concentration by six orders of magnitude. Figure 5 illustrates the effectiveness of early barrier emplacement. The maximum effectiveness can be achieved by installing the barrier as soon as possible after the leak occurs, when the contaminants are farthest away from the water table.

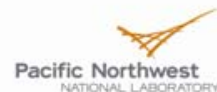


PNNL-22483

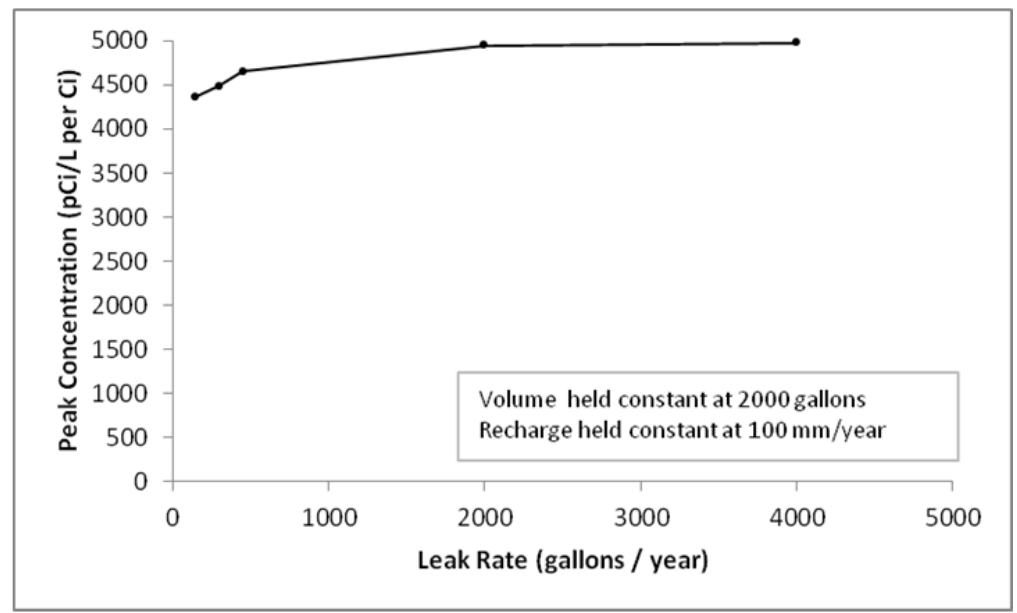

Figure 3. Effects of Leak Rate on Peak ${ }^{99} \mathrm{Tc}$ Groundwater Concentration

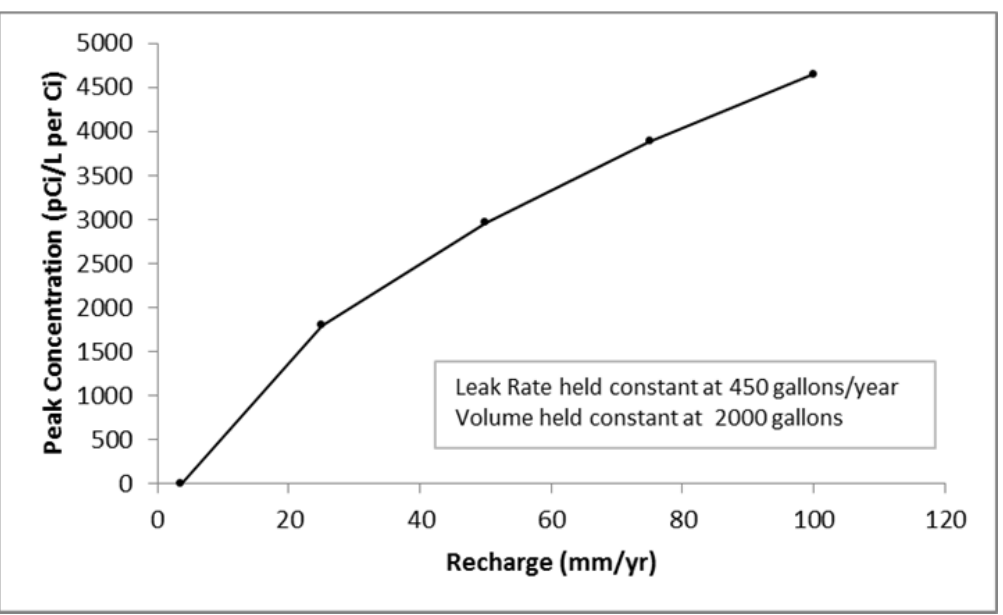

Figure 4. Effects of Recharge on Peak ${ }^{99} \mathrm{Tc}$ Groundwater Concentration

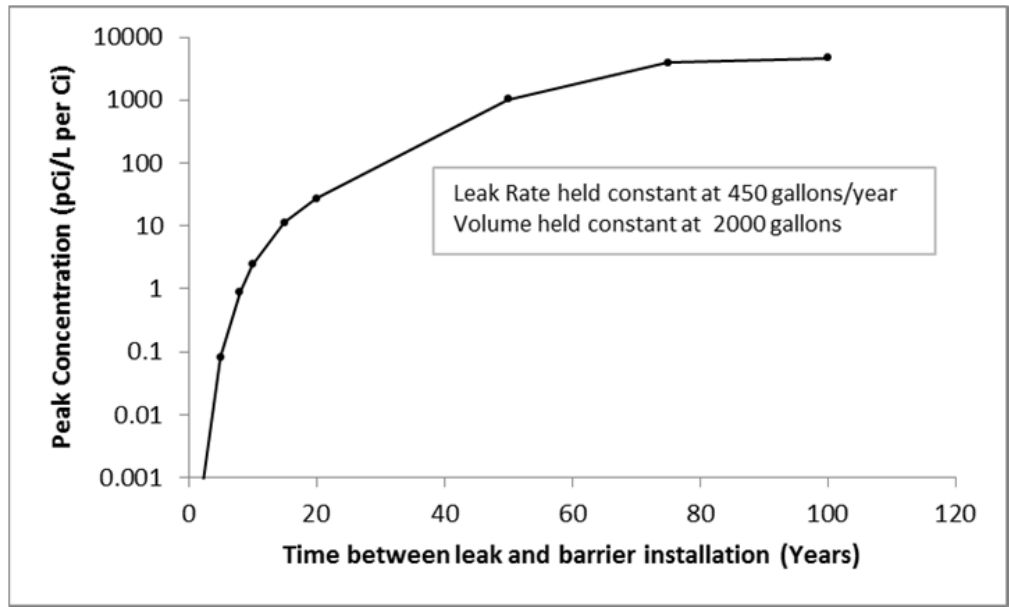

Figure 5. Effects of Infiltration Barrier Installation Delay on Peak ${ }^{99} \mathrm{Tc}$ Groundwater Concentration 
PNNL-22483

\section{Systems-Based Understanding of the Risk from Tank Leaks}

The previous sections provide several insights for understanding new tank leaks and the potential for future leaks.

- The estimated T-111 leak is relatively small in volume and contaminant inventory compared to past leaks.

- Past simulation studies indicate that a leak of similar magnitude to T-111 would be unlikely to impact groundwater at levels approaching drinking water standards.

- Several past leaks, such as those from the 1951 release from tank BX-102, are adversely affecting groundwater today and threaten even greater impacts if additional actions are not implemented.

- The population of SSTs shows considerable variation in the potential threat to the environment based on differences in the inventory of ${ }^{99} \mathrm{Tc}$ and the volume of drainable liquid.

- Sensitivity analyses show that controlling the water flux through the tank farms can be very important in mitigating the impact from recent and possible future tank leaks.

These insights underscore the necessity for a systems-based understanding of the risks from tank leaks and using that understanding to guide actions to ensure extended safe storage of tank waste, set risk-informed cleanup priorities, and define scientifically defensible approaches for remediating subsurface contamination from previous tank leaks.

DOE must take informed actions to safely manage the extended storage period for SSTs and to quantify and mitigate the risks from past discharges. Continuing federal budget pressures necessitate evaluation of the costs and benefits of possible mitigation actions. A systems-based approach is needed to understand the impact of past and current discharges and to develop and implement cost-effective remediation approaches including advanced methods for:

- delineating soil moisture and contaminant releases

- understanding and controlling contaminant mass-flux

- accessing and remediating deep vadose zone and groundwater plumes.

This system-based approach will enable DOE to develop and apply technically defensible methods that focus limited resources to mitigate the flux of contaminants and protect groundwater.

\section{Assessing the Risks from Subsurface Contamination}

Release of waste into the subsurface environment is isolated such that exposure through direct contact is not a factor in its risk to human health and the environment. Rather, movement of contamination through the vadose zone to groundwater is the pathway for exposure and risk to receptors. Assessing the threat to groundwater requires an understanding of flux rates through the vadose zone from past, current, and potential future discharges. 
DOE has previously invested in efforts to build the scientific foundation for improved understanding of subsurface contaminant transport. The Groundwater-Vadose Zone Integration Project, Environmental Management Science Program, and Subsurface Biogeochemical Research Program improved understanding of processes that control the behavior contaminants. These efforts also developed conceptual and numerical models that are now used to describe past and potential future migration events beneath the tanks (Christensen et al. 2007, Oostrom et al. 2010, Ward et al. 2003, Ward et al. 2006a, Kowalsky et al. 2005, Ward et al. 2006b, Ward and Zhang 2007, Zachara et al. 2012, Zachara et al. 2013).

Current efforts within the DOE Office of Environmental Management (EM) Deep Vadose Zone-Applied Field Research Initiative (DVZAFRI) are developing and implementing the tools and scientific approaches to conduct mass fluxbased assessments (Truex et al. 2009, 2012a, 2012b;

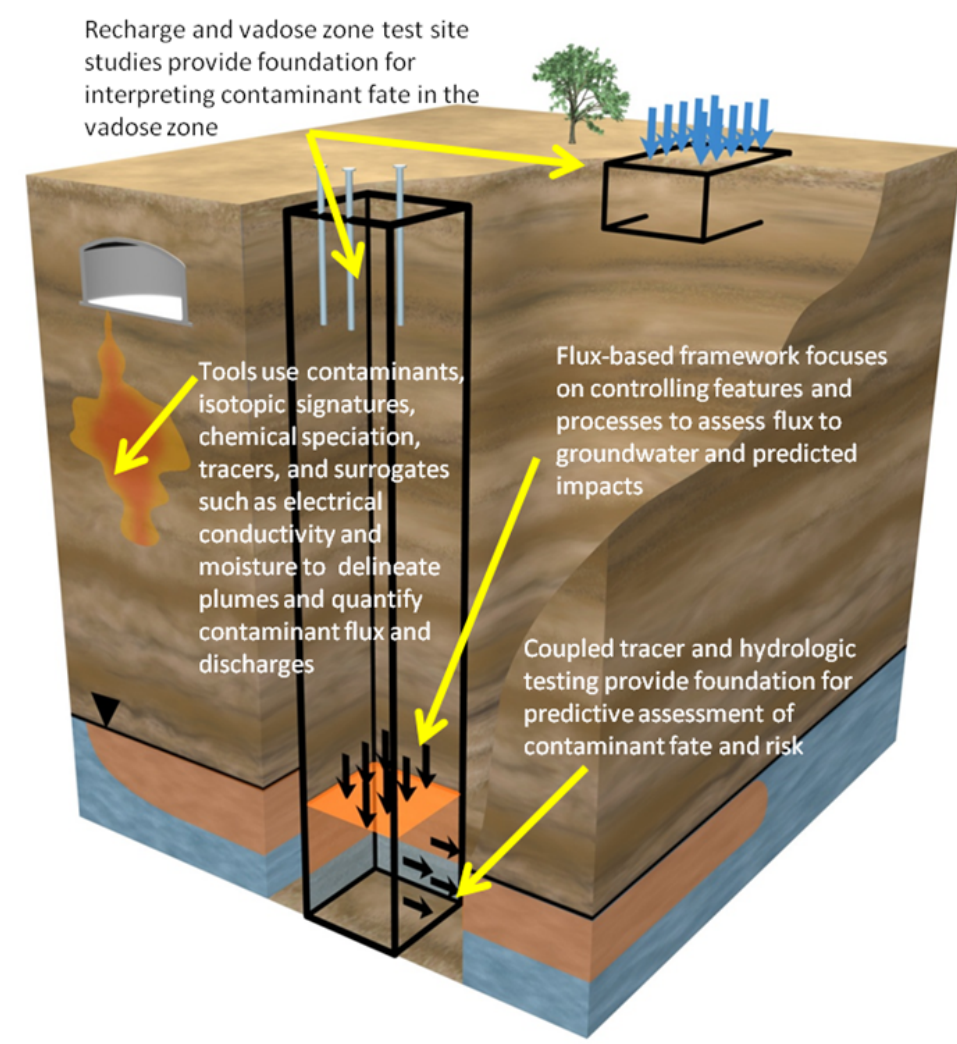
Carroll et al. 2012, 2013; Brusseau et al. 2010; Johnson et al. 2013). Mass flux-based assessments improve our understanding of subsurface contaminant transport by describing contaminant behavior and by relating that transport to actual exposure pathways (Truex and Carroll 2013). This understanding enables

- evaluation and quantification of the risks posed by subsurface contamination to human health and the environment

- design of effective remediation strategies that mitigate risk.

To enhance this understanding, innovative geophysical characterization methods have been developed and implemented that more accurately map vadose zone plume volumes and contaminant distributions and that provide quantitative measures of vadose zone moisture content-a key factor in identifying discharges to the vadose zone and in evaluating contaminant flux to groundwater (Johnson et al. 2013).

\section{Technically Defensible Strategy for Managing the Risks of Extended Waste Storage in SSTs}

Cost-effective and technically defensible remediation decisions must be based on a systems-based analysis of risk. For past, present, and potential future discharges, these decisions can include new storage options and monitoring systems, mass flux-based assessments, and remedy evaluations that quantify risk and enable effective design and implementation of mitigation actions. Infiltration covers, in-situ remediation actions such as pore water extraction or soil desiccation, retrieval of tank waste to above-ground dry storage, and construction of new tanks are just some of the options that could be considered. Technically defensible decision making requires an 
accurate understanding of the tank storage system, the subsurface environment, and cost-risk-benefit factors related to possible mitigation actions.

The following actions are essential elements of a holistic strategy for managing the long-term risks from extended storage of waste in SSTs:

1. Improve capabilities for intrusion and leak detection (both inside and outside of tanks).

2. Develop defensible conceptual models of intrusion and leak mechanisms that also account for the confounding nature of on-going physical and chemical changes in tank waste.

3. Apply enhanced subsurface characterization methods, such as electrical resistivity, to improve detection of moisture changes beneath tanks.

- In-tank instruments are necessary but not sufficient for detecting leaks.

- Advanced computational methods for electrical resistivity tomography techniques could improve detection and characterization of SST leaks.

4. Maintain a flux-based assessment of past, present, and potential future tank leaks to accurately assess the risks to human health and the environment, and to maintain risk-based priorities for mitigation actions.

5. Implement and maintain effective mitigation and remedial actions to protect groundwater resources.

- Conduct deep vadose zone treatability tests to quantify and understand the risks associated with deep vadose zone contaminants and to develop and implement appropriate technologies to reduce the mobility.

- Evaluate and apply appropriate methods to control flux by building on experience with existing infiltration barriers and the emerging deep vadose zone remediation methods such as desiccation, pore-water extraction, mass-removal methods (e.g., perched water removal), and contaminant sequestration.

- Implement appropriate groundwater treatment in areas that do not have active treatment.

This strategy must draw on expertise and initiatives within EM's Waste Management, Site and Facility Restoration, and Soil and Groundwater Remediation programs. It also must integrate with site operation activities (DOE Office of River Protection and Washington River Protection Solutions; DOE Richland Operations Office and CH2M Hill Plateau Remediation Contractor). Finally, this strategy must leverage investments in the DVZ-AFRI and in the Advanced Simulation Capability for Environmental Management (ASCEM) modeling initiative. This collaborative approach will provide the necessary scientific foundation for making defensible, risk-informed decisions that are acceptable to regulators, cost-effective, and successfully meet cleanup goals for one of DOE EM's most difficult problems.

For more information, contact Dawn Wellman at (509) 375-2017 or dawn.wellman@pnnl.gov. 


\section{References}

Brusseau, M.L., V.J. Rohay, and M.J. Truex. 2010. Analysis of soil vapor extraction data to evaluate masstransfer constraints and estimate mass flux. Ground Water Monitoring and Remediation, 30(3):57-64.

Carroll, K.C., M. Oostrom, M.J. Truex, V.J. Rohay, and M.L. Brusseau. 2012. Assessing Performance and Closure for Soil Vapor Extraction: Integrating Vapor Discharge and Impact to Groundwater Quality. J. Contam. Hydrol., 128:71-82.

Carroll, K.C., M.J. Truex, M.L. Brusseau, K.R. Parker, R.D. Mackley, and V.J. Rohay. 2013. Characterization of Persistent Volatile Contaminant Sources in the Vadose Zone. Ground Water Monitoring and Remediation. doi: 10.1111 /gwmr.12006.

Cary, A. 2013. Governor Inslee: Six Hanford Tanks Are Leaking. Tri-City Herald. February 22, 2013. Accessed May 2013 at http://www.tri-cityherald.com/2013/02/22/2285387/governor-inslee-six-hanfordtanks.html (last updated February 22, 2013).

Christensen, J.N., M.E. Conrad, D. J. DePaolo, and P.E. Dresel. 2007. Isotopic Studies of Contaminant Transport at the Hanford Site, Washington. Vadose Zone J., 6(4):1018-1030.

Corbin, R.A., B.C. Simpson, M.A. Anderson, W. Danielson III, J.G. Field, T.E. Jones, M.D. Freshley, and C.T. Kincaid. 2005. Hanford Soil Inventory Model, Rev. 1. RPP-26744, Rev. 0, CH2M HILL Hanford Group, Inc., Richland, Washington.

DOE. 2006. Initial Single-Shell Tank System Performance Assessment for the Hanford Site. DOE/ORP-2005-01, Rev. 0., U.S. Department of Energy, Richland, WA.

DOE. 2008. RCRA Facility Investigation Report for Hanford Single-Shell Tank Waste Management Areas. DOE/ORP2008-01, Rev. 0, U.S. Department of Energy, Office of River Protection, Richland, WA.

DOE. 2011. Hanford Site Groundwater Monitoring Report for 2011. DOE/RL-2011-118, Rev. 0, U.S. Department of Energy, Richland, Washington.

DOE. 2012. Final Tank Closure and Waste Management Environmental Impact Statement for the Hanford Site, Richland Washington. DOE/EIS-0391, U.S. Department of Energy, Office of River Protection, Richland, WA.

Engelman, D.B. and C.E. Jenkins. 1994. Managing the Assumed Leak from Single-Shell Tank 241-T-111. WHC-SDWM-ER-337, Rev. 0, Westinghouse Hanford Company, Richland, WA.

Johnson, T.J., M. Oostrom, M.J. Truex, J.N. Thomle, and T.W. Wietsma. 2013. Determination of water saturation using gas phase partitioning tracers and time-lapse electrical conductivity measurements. In Press, Vadose Zone J.

Jones, T.E., B.C. Simpson, M.I. Wood, and R.A. Corbin. 2000. Preliminary Inventory Estimates for Single-Shell Tank Leaks in T, TX, and TY Tank Farms. RPP-7218, Rev. 0, CH2M HILL Hanford Group, Inc., Richland, WA.

Kowalsky, M.B., S.A. Finsterle, J. Peterson, S. Hubbard, Y. Rubin, E.L. Majer, A.L. Ward, and G.W.

Gee. 2005. Estimation of field-scale soil hydraulic and dielectric parameters through joint inversion of GPR and hydrological data. Water Resources Research 41(11):W11425 1-19.

Myers, D.A. 2005. Field Investigation Report for Waste Management Areas T and TX-TY. RPP-23752, Rev. 0-A, CH2M Hill Hanford Group, Richland, Washington.

Oostrom, M., M.J. Truex, G.D. Tartakovsky, and T.W. Wietsma. 2010. Three-dimensional simulation of volatile organic compound mass flux from the vadose zone to groundwater. Groundwater Monitoring and Remediation, $30(3): 45-56$. 
PNNL. 2013. Tank W aste Information System: Best Basis Inventory. Pacific Northwest National Laboratory, Richland, WA. Accessed May 2013 at https://twins.labworks.org/twinsdata/Forms/About.aspx?subject=BestBasisInventory (last updated January 2013).

Rodgers, M.J. 2012. Waste Tank Summary Report for Month Ending August 31, 2012. HNF-EP-0182, Rev. 293, Washington River Protection Solutions, Richland. WA.

Serne, R.J., P.D. Thorne, G.S. Thomas, B.N. Bjornstad, D.C. Lanigan, J.M. Keller, and J.N. Christensen. 2010. Conceptual Models for Migration of Key Groundwater Contaminants Through the Vadose Zone and Into the Unconfined Aquifer Below the B-Complex. PNNL-19277, Pacific Northwest National Laboratory, Richland, WA.

Truex, M.J. and K.C. Carroll. 2013. Remedy Evaluation Framework for Inorganic, Non-Volatile Contaminants in the Deep Vadose Zone. PNNL-21815, Pacific Northwest National Laboratory, Richland, WA.

Truex, M.J., K.C. Carroll, V.J. Rohay, R.M. Mackley, and K.R. Parker. 2012a. Treatability Test Report: Characterization of V adose Zone Carbon Tetrachloride Source Strength Using Tomographic Methods at the 216-Z-9 Site. PNNL-21326, Pacific Northwest National Laboratory, Richland, WA.

Truex, M.J., M. Oostrom, and M.L. Brusseau. 2009. Estimating Persistent Mass Flux of Volatile Contaminants from the Vadose Zone to Groundwater. Ground Water Monitoring and Remediation, 29(2):63-72.

Truex, M.J., V.R. Vermeul, B.G. Fritz, R.D. Mackley, J. Horner, D.R. Newcomer, and C.D. Johnson. 2012b. Investigation of Hexavalent Chromium Flux to Groundwater at the 100-C-7:1 Excavation Site. PNNL-21845, Pacific Northwest National Laboratory, Richland, WA.

Ward, A.L. and Z.F. Zhang. 2007. Effective Hydraulic Properties Determined from Transient Unsaturated Flow in Anisotropic Soils. V adose Zone Journal, 6(4):913-924.

Ward, A.L., G.W. Gee, Z.F. Zhang, and J.M. Keller. 2003. Vadose Zone Transport Field Study: FY 2002 Status Report. PNNL-14150, Pacific Northwest National Laboratory, Richland, WA.

Ward, A.L., M.E. Conrad, W.D. Daily, J.B. Fink, V.L. Freedman, G.W. Gee, G.M. Hoversten, J.M. Keller, E.L. Majer, C.J. Murray, M.D. White, S.B. Yabusaki, and Z.F. Zhang. 2006a. Vadose Zone Transport Field Study: Summary Report. PNNL-15443, Pacific Northwest National Laboratory, Richland, WA.

Ward, A.L., Z.F. Zhang, and G.W. Gee. 2006b. Upscaling unsaturated hydraulic parameters for flow through heterogeneous anisotropic sediments. Advances in Water Resources, 29(2):268-280.

Zachara, J.M., M.D. Freshley, G.V. Last, R.E. Peterson, and B.N. Bjornstad. 2012. Updated Conceptual Model for the 300 Area Uranium Groundwater Plume. PNNL-22048, Pacific Northwest National Laboratory, Richland, WA.

Zachara, J.M., P.E. Long, J. Bargar, J.A. Davis, P.M. Fox, J.K. Fredrickson, M.D. Freshley, A. Konopka, C. Liu, J.P. McKinley, M.L. Rockhold, K.H. Williams, and S.B. Yabusaki. 2013. Persistence of uranium groundwater plumes: Contrasting mechanisms at two DOE sites in the groundwater-river interaction zone. In Press, Journal of Contaminant Hydrology.

Zhang, Z.F., V.L. Freedman, S.R. Waichler, and M.D. White. 2004. 2004 Initial Assessments of Closure for the S-SX Tank Farm: Numerical Simulations. PNNL-14604, Pacific Northwest National Laboratory, Richland, WA. 